\title{
Distribution of Native Lactic Acid Bacteria in Wineries of Queretaro, Mexico and Their Resistance to Wine-Like Conditions
}

OPEN ACCESS

Edited by: Giovanna Suzzi,

University of Teramo, Italy

Reviewed by:

Giuseppe Spano,

University of Foggia, Italy

Jose Antonio Curiel,

Instituto de Ciencias de la Vid y del

Vino, Spain

*Correspondence:

Sofía M. Arvizu-Medrano

sofia.arvizu@uaq.mx

Specialty section:

This article was submitted to

Food Microbiology,

a section of the journal

Frontiers in Microbiology

Received: 17 August 2016 Accepted: 21 September 2016 Published: 08 November 2016

Citation:

Miranda-Castilleja $D E$ Martínez-Peniche RÁ, Aldrete-Tapia JA, Soto-Muñoz L, Iturriaga $\mathrm{MH}$, Pacheco-Aguilar JR and Arvizu-Medrano SM (2016) Distribution of Native Lactic Acid Bacteria in Wineries of Queretaro, Mexico and Their Resistance to Wine-Like Conditions.

Front. Microbiol. 7:1769. doi: 10.3389/fmicb.2016.01769

\section{Dalia E. Miranda-Castilleja, Ramón Álvar Martínez-Peniche, J. A. Aldrete-Tapia, Lourdes Soto-Muñoz, Montserrat H. Iturriaga, J. R. Pacheco-Aguilar and Sofía M. Arvizu-Medrano *}

Departamento de Investigación y Posgrado en Alimentos, Facultad de Química, Universidad Autónoma de Querétaro, Santiago de Querétaro, Mexico

Native lactic acid bacteria $(\angle A B)$ are capable of growing during winemaking, thereby strongly affecting wine quality. The species of $L A B$ present in musts, wines during malolactic fermentation (MLF), and barrels/filters were investigated in wineries from the emerging wine region of Queretaro, México using multiplex PCR and culture. The resistance to wine-like conditions (WLC): ethanol (10, 12, and 13\%), $\mathrm{SO}_{2}$ (30 $\mathrm{mg} \cdot \mathrm{I}^{-1}$ ), and low $\mathrm{pH}$ (3.5) of native LAB strains was also studied. Five species were detected within 61 samples obtained: Oenococcus oeni, Lactobacillus plantarum, Pediococcus parvulus, Lactobacillus hilgardi, and Lactobacillus brevis. Four species (excepting $L$. brevis) were found in must; $O$. oeni and $P$. parvulus were ubiquitous in wine and $L$. plantarum and $L$. brevis were mainly present at the initial stage of MLF, while L. hilgardii was mostly detected at the advanced stage. Furthermore, some species detected in barrel/filter, prove them to be hazardous reservoirs. From 822 LAB isolates, only 119 resisted WLC with $10 \%$ ethanol; the number of strains able to grow in WLC with $13 \%$ ethanol decreased approximately by $50 \%$, O. oeni being the most versatile species with $65 \%$ of resistant isolates, while Lactobacillus spp. and $P$. parvulus were the most strongly affected, especially those recovered from barrel/filter, with less than $10 \%$ of resistant isolates. This study evidences the presence of local strains able to be used as starter cultures, and also enabled the assessment of the risks derived from the presence of spoilage LAB strains resistant to WLC.

Keywords: malolactic fermentation, multiplex PCR, Oenococcus oeni, starter cultures, wine spoilage

\section{INTRODUCTION}

The conversion from grape must into wine is a complex process that involves the development of various microorganisms, including lactic acid bacteria (LAB). However, wine is considered an unsuitable environment for microbial growth due to its low $\mathrm{pH}$, high concentrations of ethanol and sulfur dioxide $\left(\mathrm{SO}_{2}\right)$, and other limiting factors (Spano and Massa, 2006). The LAB capable of overcoming these conditions mainly belong to Oenococcus, Lactobacillus, Pediococcus, and Leuconostoc genera (Lonvaud-Funel, 1999). 
In order to have any effect on wine quality, LAB should be able to not only survive, but also to grow within wine (Renouf et al., 2008), and the effect produced therein will depend on the major species present and their ability to overcome the harsh environment of winemaking (du Toit and Pretorius, 2000). The specie Oenococcus oeni is known as the main one responsible for malolactic fermentation (MLF), a process in which Lmalic acid is decarboxylated into L-lactic acid, causing a partial deacidification, conferring microbial stability, and improving wine flavor profile (Lerm et al., 2010). However, some other LAB, such as Pediococcus spp. and some species of Lactobacillus, are widely associated with wine spoilage, often producing biogenic amines, off-odors, and other undesirable metabolites (Bartowsky, 2009).

Moreover, LAB can enter wine from vineyard or winery equipment (Fleet, 1993), and their diversity is influenced by grape variety and geographic region (Bokulich et al., 2013b). Therefore, it is advisable to study the autochthonous LAB of a particular winemaking area in order to detect potential starter cultures or species that represent risks of wine spoilage (Pérez-Martín et al., 2014). The use of molecular techniques to achieve this porpoise is currently preferred; some of them, such as ARDRA (Rodas et al., 2003), DGGE (Cocolin et al., 2013), or new generation sequencing (Bokulich et al., 2013a), display all the diversity of bacteria present in a sample. Meanwhile, other techniques, such as multiplex PCR described by Petri et al. (2013), are aimed at those bacteria of particular interest in winemaking. This particular technique allows the identification of 13 of the principal LAB associated with winemaking in a simple PCR assay, facilitating data processing or subsequent analyses to complete the identification of an amplicon.

Several studies intending to elucidate the presence, distribution, and adaptation of wine associated LAB have already been performed in wineries from regions with an extensive winemaking tradition, such as Mentrida (PérezMartín et al., 2014), La Rioja (González-Arenzana et al., 2015), Patagonia (La Hens et al., 2015), and Apulia (Garofalo et al., 2015). However, this kind of studies are missing in areas where the development of this industry is recent, like Queretaro State in Mexico. This region is considered nowadays the second most important within the Mexican territory. Located in the central area of the country, the climate is semi dry and temperate, the soils are deep with either a clayey loam texture or lightly calcareous. In 2013, above 350 ha of vineyards were censed and wine production was estimated in 1.5 millions of liters (Consejo Mexicano Vitivinícola A.C [CMV], 2014). To date, the main varieties established are 'Merlot,' 'Cabernet Sauvignon', 'Syrah', and 'Tempranillo' as well as the white varieties 'Macabeo' and 'Chardonnay' (Asociación de Vitivinicultores de Querétaro [AVQ], 2011). Wines possess low ethanol contents (from 9 to 12\%) and a total titratable acidity around $7 \mathrm{~g} / \mathrm{L}$ tartaric acid (De la Cruz-de Aquino et al., 2012). Wineries usually use commercial yeasts to guarantee an optimal alcoholic fermentation, but MLF is almost always carried out spontaneously, which makes it very unpredictable.
The aim of this research was to elucidate the principal LAB species present in strategic materials in wineries established in Queretaro and to determine their resistance to wine-like conditions (WLC), including high ethanol concentrations and low $\mathrm{pH}$, in order to assess risks and detect possible starter cultures within local strains.

\section{MATERIALS AND METHODS}

\section{Experimental Site and Sampling}

This study was conducted in four wineries named A, B, C, and D, located in Queretaro State, Mexico. Wineries A, B, and $C$ have the respective vineyards and are located in the municipality of Ezequiel Montes, approximately $205 \mathrm{~km}$ from Mexico City. Winery D lacks a vineyard and is located $21 \mathrm{~km}$ from the others, in the municipality of Tequisquiapan. At winery $\mathrm{C}$ commercial cultures of LAB are used to induce MLF after finishing alcoholic fermentation; at winery $\mathrm{B}$ a commercial inoculum of LAB was used for the first time the year of the study, and at wineries A and D, MLF is left to occur spontaneously.

Depending on the availability at the wineries, different types of samples were collected, their characteristics are described in Table 1. Must, wine and barrel/filter samples were taken at winery A; must and wine at winery B; only must at winery $\mathrm{C}$ and only wine at winery D. Each type of sample was collected in triplicate as follows:

(i) Must: Four mature bunches of grapes from the varieties: 'Cabernet Sauvignon,' 'Tempranillo,' and 'Syrah' at wineries $\mathrm{A}$ and $\mathrm{B}$, and only 'Macabeo' at $\mathrm{C}$, were randomly sampled in triplicates using plastic bags $(20 \mathrm{~cm} \times 30 \mathrm{~cm})$. Also, $500 \mathrm{ml}$ of must were taken from the stemmer of wineries $A$ and $B$ (one and two batches, respectively). Once they reached the laboratory, bunches were manually crushed inside their bags, the musts obtained from grapes and those collected from the stemmers were transferred to sterile flasks $(500 \mathrm{ml})$ and left to spontaneously ferment at $25^{\circ} \mathrm{C}$. For 15 days, aliquots of fermenting must were obtained every 5 days for molecular and microbial analyses.

(ii) Wine: Samples were taken once the alcoholic fermentation had ended. At wineries A and D, $100 \mathrm{ml}$ of wine were sampled from three fermentation tanks, in three stages of MLF: (a) beginning, (b) intermediate, and (c) advance. At winery $\mathrm{B}$, only the beginning stage was sampled, before a commercial strain inoculation. At each winery three types of wines were collected: two single-variety, one 'Cabernet Sauvignon, another 'Tempranillo,' and the third a blend of 'Grenache,' 'Carignan,' 'Syrah,' and 'Nebbiolo.'

(iii) Barrel/filter: The inside of a barrel was rinsed with $500 \mathrm{ml}$ of peptone diluent $(0.1 \%, \mathrm{pH} 5)$, which was swirled five times; afterward the diluent was recovered in a sterile flask. Three filters were also individually collected in plastic bags. Once they reached the laboratory, $100 \mathrm{ml}$ of peptone diluent was added to each filter and then homogenized in a Stomacher ${ }^{\circledR}$ 400 (Seward Ltd.) at medium speed for $1 \mathrm{~min}$. 
TABLE 1 | Principal characteristics of the samples collected.

\begin{tabular}{|c|c|c|c|c|c|c|}
\hline Winery & Sample type & $\mathbf{N}^{1}$ & Sugar content ( $\left.{ }^{\circ} \mathbf{B x}\right)$ & $\mathrm{pH}$ & Ethanol $(\%, v / v)$ & $\mathrm{SO}_{2}$ Total $\left(\mathrm{mg} \cdot \mathrm{L}^{-1}\right)$ \\
\hline \multirow[t]{5}{*}{ A } & Must & 12 & 23 & 3.8 & - & - \\
\hline & Wine-i & 3 & 5 & 3.4 & 12.1 & 31.5 \\
\hline & Wine-m & 3 & 5 & 3.6 & 12.1 & 31.5 \\
\hline & Wine-a & 3 & 5 & 3.7 & 12.1 & 31.5 \\
\hline & Barrel/filter & 4 & - & - & - & - \\
\hline \multirow[t]{2}{*}{$B$} & Must & 15 & 22 & 3.8 & - & - \\
\hline & Wine-i & 3 & 5 & 3.4 & 11.9 & 29.8 \\
\hline C & Must & 9 & 21 & 3.7 & - & - \\
\hline \multirow[t]{3}{*}{$D$} & Wine-i & 3 & 4 & 4.1 & 12.6 & 33.1 \\
\hline & Wine-m & 3 & 4 & 3.7 & 12.6 & 33.1 \\
\hline & Wine-a & 3 & 4 & 3.8 & 12.6 & 33.1 \\
\hline
\end{tabular}

${ }^{1}$ Total number of samples.

Data reported as mean of three replicates per sample analyzed.

\section{LAB Enumeration and Isolation}

Must, wine and barrel/filter rinse aliquots $(1 \mathrm{~mL})$ were taken for serial dilutions and plated in three culture media: Man Rogosa Sharpe (MRS; DIBICO), MRS added to tomato juice $(10 \%, \mathrm{v} / \mathrm{v}$; Ruiz et al., 2008) or to apple juice (15\%, v/v; Solieri et al., 2010). All media were adjusted to $\mathrm{pH} 4.8$ and supplemented with natamycin $\left(100 \mathrm{mg} \cdot \mathrm{l}^{-1}\right)$ and sodium azide $\left(50 \mathrm{mg} \cdot \mathrm{l}^{-1}\right)$ to prevent yeast and acetic acid bacteria growth, respectively (Reguant et al., 2005). Incubation was carried out at $30^{\circ} \mathrm{C}$ for 8 days. As bacterial population is a non-normal data, the results were statistically analyzed using the non-parametric Kruskal - Wallis with Dunn's post hoc test using the software JMP 9.0.

From culture plates, approximately $5 \%$ of the colonies were isolated and purified. Gram stain and catalase tests were performed to confirm the isolates belonging to LAB group. Isolates were preserved in MRS broth with glycerol $20 \%$ at $-80^{\circ} \mathrm{C}$ until subsequent identification and resistance tests.

\section{Isolates Resistance to Wine-Like Conditions}

The isolates' ability to grow in the presence of ethanol, $\mathrm{SO}_{2}$, and low $\mathrm{pH}$ (WLC) was assessed through automatic readings of optical density (OD; every $20 \mathrm{~min}$, for $72 \mathrm{~h}$, at $30^{\circ} \mathrm{C}$ ) using a Bioscreen ${ }^{\odot}$ analyzer (Miranda-Castilleja et al., 2015). Approximately $5 \mathrm{Log} \mathrm{CFU} \cdot \mathrm{ml}^{-1}(\mathrm{OD}=0.2)$ of each $\mathrm{LAB}$ isolate were inoculated in individual wells containing $200 \mu \mathrm{L}$ of synthetic medium similar to wine (SW, Carreté et al., 2002) added to $53 \mathrm{mg} \cdot \mathrm{l}^{-1}$ of potassium metabisulfite (equivalent to $30 \mathrm{mg} \cdot \mathrm{l}^{-1}$ $\left.\mathrm{SO}_{2}\right), \mathrm{pH} 3.5$, and ethanol $(10,12$, and $13 \%)$. As positive control, the isolates were also inoculated in the SW medium $(\mathrm{pH} 4)$ without the inhibitors. Detection time (DT), an indirect measure of the lag phase, was used as a response variable, considering the strain to be resistant to each condition when its DT value was lower than the total incubation time (72 h).

\section{Detection of LAB Species in Wineries}

The detection of species present in the wineries' samples (must, wine, and barrel/filter) and the identification of LAB isolates capable of growing in WLC were both carried out using a multiplex PCR (Petri et al., 2013).

\section{DNA Extraction}

Must, wine, and barrel/filter rinse aliquots $(15 \mathrm{~mL})$ were centrifuged $(5000 \times g, 10 \mathrm{~min})$. From a cell pellet, DNA was extracted using the commercial kit Powersoil (MoBio Laboratories, Inc.) and the bench bead-top homogenizer PowerLyzer (MoBio Laboratories, Inc.) at $4500 \mathrm{rpm}$ for $4 \mathrm{~min}$, following the manufacturer's instructions.

DNA extraction of LAB isolates was performed as follows: The strains were grown in $1 \mathrm{ml}$ of $\mathrm{MRS}$ broth at $30^{\circ} \mathrm{C}$ for 3 days. The cell pellet obtained through centrifugation $(13000 \times g, 2 \mathrm{~min})$ was re-suspended in $300 \mu \mathrm{l}$ of lysis buffer (200 mM Tris-HCl, pH 8.5, $250 \mathrm{mM} \mathrm{NaCl}, 25 \mathrm{mM}$ EDTA, 0.5\% w/v SDS) with powdered glass $(0.2 \mathrm{~g})$. The suspension was shaken in a PowerLyzer (MoBio) at $4500 \mathrm{rpm}$ for $1 \mathrm{~min}$. After centrifugation at $13000 \times g$ for $5 \mathrm{~min}, 150 \mu \mathrm{l}$ of $3 \mathrm{M}$ sodium acetate $(\mathrm{pH}$ 5.2) was added to the supernatant, which was stored at $-20^{\circ} \mathrm{C}$ for $30 \mathrm{~min}$ and then centrifuged $(13000 \times g, 10 \mathrm{~min})$. The supernatant was transferred to a new tube and nucleic acids were precipitated with $400 \mu \mathrm{l}$ of isopropanol and then washed with ethanol (70\%). Finally, the DNA was re-suspended in $25 \mu \mathrm{l}$ of TE buffer (SotoMuñoz et al., 2014).

\section{Multiplex PCR}

The multiplex PCR was done using Multiplex Mastermix (Qiagen) with $1 \mu \mathrm{L}$ of sample DNA, following the procedure described by Petri et al. (2013) with some modifications: $95^{\circ} \mathrm{C}$ for $15 \mathrm{~min}$ for initial denaturation, six cycles consisting of $30 \mathrm{~s}$ at $94^{\circ} \mathrm{C}$, annealing for $3 \mathrm{~min}$ beginning at $69^{\circ} \mathrm{C}$ with a reduction of $1^{\circ} \mathrm{C}$ each cycle and an elongation step of $1.5 \mathrm{~min}$ at $72^{\circ} \mathrm{C}$; then 25 cycles of $30 \mathrm{~s}$ at $94^{\circ} \mathrm{C}, 3 \mathrm{~min}$ at $62^{\circ} \mathrm{C}$, and $1.5 \mathrm{~min}$ at $72^{\circ} \mathrm{C}$, followed by a final extension step of $10 \mathrm{~min}$ at $72^{\circ} \mathrm{C}$. The primers used are listed in Table 2 . The PCR products were analyzed by electrophoresis on $1.8 \%$ agarose gels with TBE buffer (90 $\mathrm{V}$ for $45 \mathrm{~min}$ ). Gels were stained with ethidium bromide $\left(0.5 \mu \mathrm{g} \cdot \mathrm{ml}^{-1}\right)$ and visualized with an EDAS 290 digital imaging system (Kodak). Trackit ${ }^{\mathrm{TM}} 100 \mathrm{bp}$ (Invitrogen) was used as the standard molecular weight marker. 
TABLE 2 | Primers used for the identification of lactic acid bacteria (LAB) by multiplex PCR.

\begin{tabular}{|c|c|c|}
\hline Primer & Sequence & Target \\
\hline \multicolumn{3}{|l|}{ Primer mixture I } \\
\hline SCAR-OENI-F & GGTAGATTAACCCGCGACG & O. oeni \\
\hline SCAR-OENI-R & GGAATCGGTAGCATCCTG & \\
\hline SCAR-LBR-F & GGAAGATCAAGAATATCGGTG & L. brevis \\
\hline SCAR-LBR-R & GCGTCTCTAATTCACTGAGC & \\
\hline SCAR-LPL-F & GAAGATTTGCCCATCGGTG & L. plantarum \\
\hline SCAR-LPL-R & CGTTGATGGTAGCGTTGC & \\
\hline SCAR-LEU-F & GTGGTCATGGGTCTTAGC & Leuconostoc \\
\hline SCAR-LEU-R & GGATCAAGACTAGCCAATGG & mesenteroides \\
\hline SCAR-WPA-F & GCTGATGAACCCATACCTC & $\begin{array}{l}\text { Weissella } \\
\text { paramesenteroides }\end{array}$ \\
\hline SCAR-WPA-R & GACCTGATTCGCTCGTTG & \\
\hline SCAR-PDA-F & GTCTAAACTGGTGGTTAAACG & P. damnosus \\
\hline SCAR-PDA-R & ATCGCACCTGGTTCAATGC & \\
\hline SCAR-PPA-F & GCATGAATCACTIITCGCTC & P. parvulus \\
\hline SCAR-PPA-R & CAAAGATTGTGACCCAGTTG & \\
\hline \multicolumn{3}{|l|}{ Primer mixture II } \\
\hline SCAR-LBU-F & СTATCTTTAACCGCATTGCCG & L. buchneri \\
\hline SCAR-LBU-R & GACACGCTTCTCATGATTGTC & \\
\hline SCAR-PAC-F & ATGATGGACAGACTCCCTG & P. acidilactici \\
\hline SCAR-PAC-R & CGAGCTGCGTAGATATGTC & \\
\hline SCAR-LBH-F & TTCCTTGGTAATGTGCTTGC & L. hilgardii \\
\hline SCAR-LBH-R & AATGGCAATCGCAATGGACG & \\
\hline SCAR-PIN-F & СTATCCTTACAATGTGCATCG & P. inopinatus \\
\hline SCAR-PIN-R & TGGTGCGTCAGTAAATGTAAG & \\
\hline SCAR-LCU-F & CCAGATCCATCAGAAGATACG & L. curvatus \\
\hline SCAR-LCU-R & GCTAACTTACCACTAACGACC & \\
\hline SCAR-PPE-F & GGGAACGGTITAGTTITATACG & P. pentosaceus \\
\hline SCAR-PPE-R & CTAAGAGCGGTGATGATAAG & \\
\hline
\end{tabular}

\section{RESULTS}

\section{Enumeration and Isolation of LAB in Different Samples and Stages of MLF}

A total of 822 isolates were recovered from the counting plates of the 61 samples collected at the four wineries (Table 3). Three culture media were used in this study to improve LAB recovery; however, contrary to previous reports (Solieri et al., 2010; Schillinger and Holzapfel, 2012), the population, the morphology of the colonies observed and species identified were very similar in the different media (Supplementary Figure S1). Therefore, in Figure 1, the LAB populations are shown, independent of culture media, involving six replicates of each sample analyzed (two per culture media). The LAB counts in musts from wineries A and $\mathrm{B}$ were rather low $\left(10^{1}-10^{3} \mathrm{CFU} \cdot \mathrm{ml}^{-1}\right)$ and no bacterial growth $\left(<10 \mathrm{CFU} \cdot \mathrm{ml}^{-1}\right)$ was observed in several samples $(5 / 12$ in A and $6 / 15$ in B). By contrast, higher counts $\left(10^{4}-10^{5} \mathrm{CFU} \cdot \mathrm{ml}^{-1}\right)$ were observed in musts from winery $\mathrm{C}$, being this winery the one with the highest populations observed. In wine, the LAB populations ranged from $10^{2} \mathrm{CFU} \cdot \mathrm{ml}^{-1}$ at the beginning of the process, to $10^{9} \mathrm{CFU} \cdot \mathrm{ml}^{-1}$ at the second stage (climax of MLF), with intermediate values at the advanced stage. Finally, in barrel/filters
TABLE 3 | Number of samples handled and isolates obtained from the four wineries located in Queretaro, Mexico.

\begin{tabular}{lccc}
\hline Winery & Sample type & Total samples & Total isolates \\
\hline A & Must & 12 & 23 \\
& Wine & 9 & 213 \\
& Barrel/filter & 4 & 156 \\
B & Must & 15 & 96 \\
& Wine & 3 & 89 \\
C & Must & 9 & 103 \\
D & Wine & 9 & 142 \\
Total & & $\mathbf{6 1}$ & $\mathbf{8 2 2}$ \\
\hline
\end{tabular}

rinse, the LAB population was around $10^{8} \mathrm{CFU} \cdot \mathrm{ml}^{-1}$ being superior comparing to must but similar to the populations observed in wine.

\section{Detection and Distribution of LAB Species through the Wineries}

Five species (O. oeni, Pediococcus parvulus, Lactobacillus plantarum, Lactobacillus hilgardii, and Lactobacillus brevis) were detected among the wineries' samples (Table 4). In most of the cases, the detection by culture confirmed what was observed with the molecular detection (culture-independent). However, some discrepancies between detection approaches were observed: L. brevis in wines (from $\mathrm{A}$ and $\mathrm{B}$ ) and barrel/filter was only detected by culture. Conversely, the presence of $O$. oeni at winery $\mathrm{C}$ was only determined by direct multiplex PCR.

In several must samples (18/33), the LAB species investigated were not detected, and in the remaining ones, $L$. plantarum was widely detected at wineries A (58\%) and C (100\%). O. oeni was found in $67 \%$ of the samples from B and $56 \%$ from C. Finally, P. parvulus was only found in $8 \%$ of the samples from winery B and $L$. hilgardii only in $22 \%$ from C.

In wine samples, the five species were detected and O. oeni and $P$. parvulus were found in all samples. L. plantarum was detected in several samples from three wineries (22-56\%). L. hilgardii was only found at winery A (22\%), whereas, L. brevis was present at wineries A and B at 11 and 33\%, respectively. Additionally, $L$. brevis and $L$. plantarum were mainly detected at the first stage of MLF, and L. hilgardii predominated at the advanced stage. Finally, in barrel/filter samples, all the five species were found. Winery A showed the greatest diversity of LAB species and at winery $B$ the presence of $O$. oeni was remarkable.

\section{LAB Resistance to Increasing Ethanol Concentrations with $\mathrm{SO}_{2}$ and $\mathrm{pH}$ of 3.5}

As expected, the number of resistant isolates falls as ethanol concentration increases (Figure 2). In some samples (must from $\mathrm{C}$; wine from $\mathrm{A}$ and $\mathrm{D}$ ), the diversity of resistant species remained, with fewer individual ones capable of growing with $13 \%$ ethanol, evidencing strain variation. Moreover, the number of resistant $O$. oeni isolates remained unchanged, even with higher ethanol concentrations, which is particularly notable at winery B. Conversely, P. parvulus was strongly affected by higher ethanol levels, particularly those isolates obtained from 
TABLE 4 | Percentage of incidence of LAB species detected by culture (C) and molecular assay (M) in samples of must, wine in three stages of malolactic fermentation (MLF): Initial (i), middle ( $m$ ), and advanced (a) and barrel/filter; obtained in wineries A, B, C, and D.

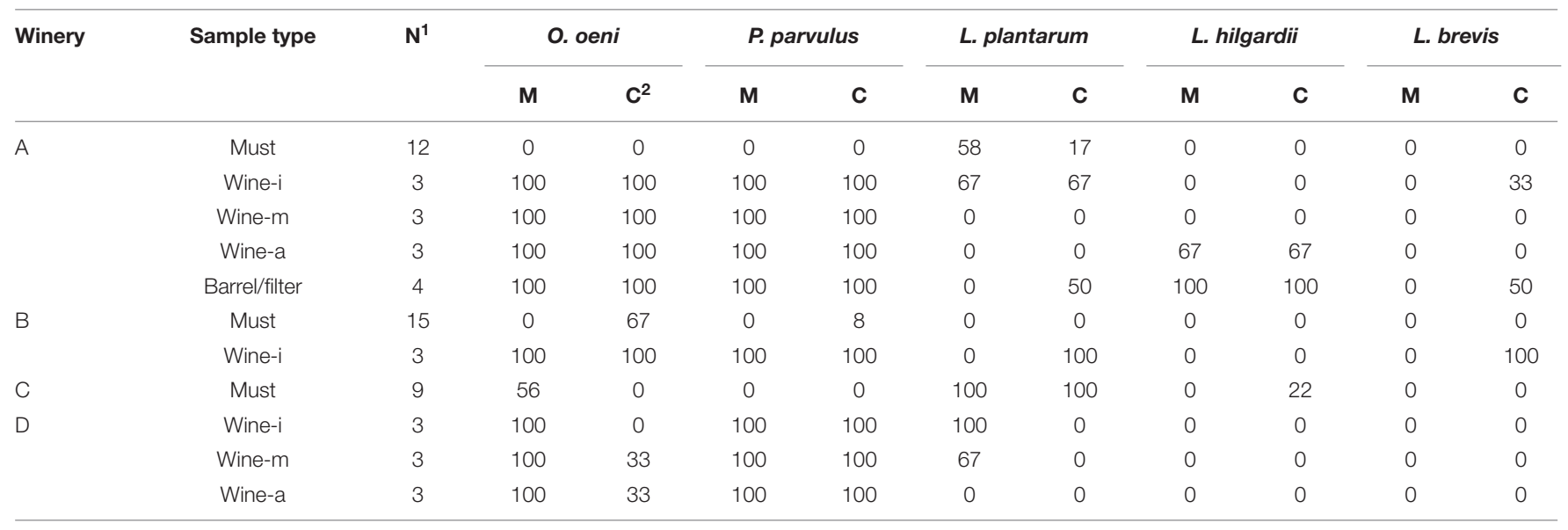

${ }^{1} \mathrm{~N}$ : number of samples analyzed.

${ }^{2}$ Culture-dependent approach: identifying isolates resistant to wine-like conditions (WLC) with 10\% ethanol.

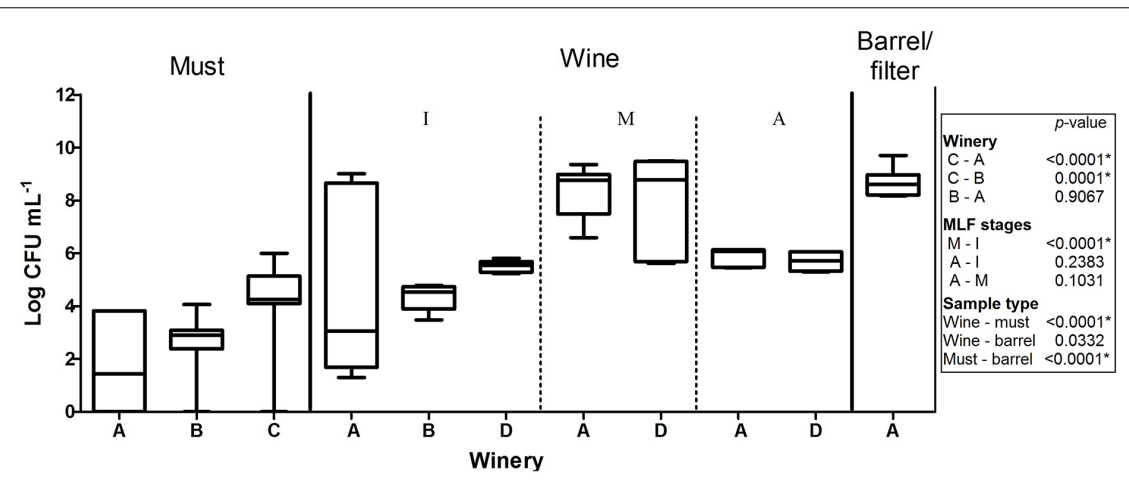

FIGURE 1 | Population of lactic acid bacteria in samples of must, barrel/filter and wine throughout three stages of malolactic fermentation: I beginning, M intermediate, A advanced; obtained from wineries (A-D). Kruskal-Wallis analysis and Dunn's post hoc test among wineries, MFL stages and sample type. The box indicates the 25th and 75th percentiles, line across the box shows the median value and the whiskers caps represent the maximum and minimum values.

barrel/filter, of which around $90 \%$ did not resist $13 \%$ ethanol. The Lactobacillus spp. in this study were also affected by $13 \%$ ethanol, with only $37 \%$ of the isolates being resistant to this condition. Finally, the high number of isolates (10 of 19) from must from winery $\mathrm{C}$ resistant to $13 \%$ ethanol is remarkable, given their origin.

\section{DISCUSSION}

\section{LAB Populations}

The low LAB populations found in musts are consistent with the fact that they are minor constituents of grape microbiota, the populations usually reported being around $10^{2} \mathrm{CFU} \cdot \mathrm{g}^{-1}$ (Barata et al., 2012). Meanwhile, higher populations found in must from winery $\mathrm{C}$ could be associated with grape variety; must from winery $\mathrm{C}$ was obtained from a white variety ('Macabeo'), while musts from wineries A and B derived from red varieties ('Tempranillo,' 'Syrah', and 'Cabernet Sauvignon').
Higher numbers of LAB obtained from white varieties compared to red ones were also reported by Bae et al. (2006), which has been attributed to the fact that some phenolic compounds only present in red varieties can produce a toxic effect on bacteria (Reguant et al., 2000). The fluctuating populations of LAB observed in wine at different stages of MLF coincides with Saguir et al. (2009) and González-Arenzana et al. (2012), who reported that lower counts of LAB at the beginning of MLF increased throughout the process, reaching up to $8 \mathrm{Log} \mathrm{CFU} \cdot \mathrm{ml}^{-1}$.

Furthermore, barrel/filter samples were considered together in this study since the barrel contained the wine in which the filters were used, and only a few samples of each material could be collected. In particular, the LAB population found in barrels $\left(10^{3}\right.$ $\mathrm{CFU} \cdot \mathrm{ml}^{-1}$ ) was similar to that reported by González-Arenzana et al. (2013). Barrels are recognized as microbial reservoirs in cellars, since they offer shelter where microorganisms can remain. However, this material also represents a stressful environment, which could explain the low populations encountered therein (Renouf et al., 2007; Bokulich et al., 2013a). 


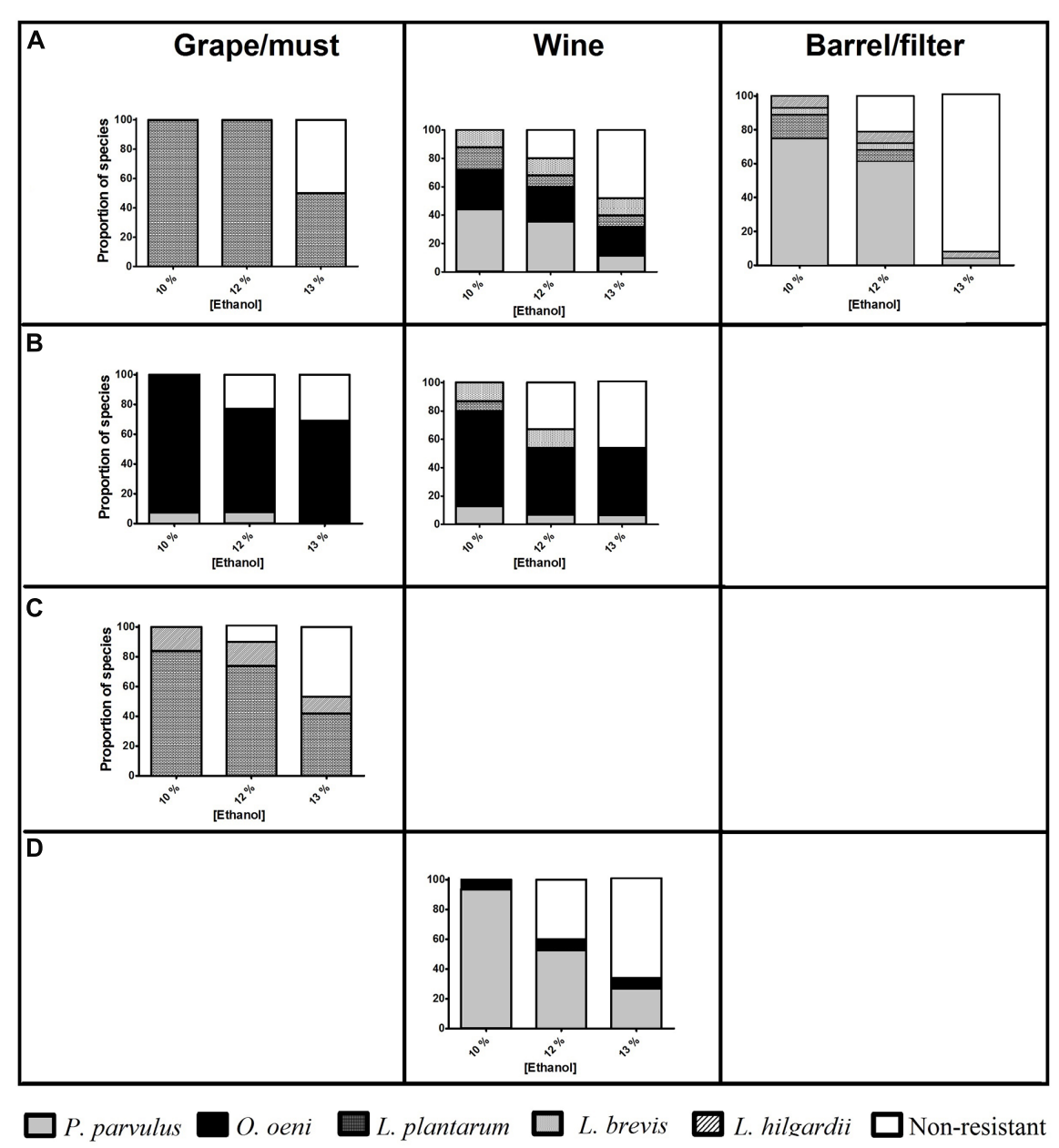

FIGURE 2 | Proportion of isolates of lactic acid bacteria (LAB) species capable of growing in a synthetic medium similar to wine (SW) with $\mathrm{SO}_{2} 30 \mathrm{mg}$ $\mathrm{I}^{-1} \mathrm{pH} 3.5$ and different ethanol concentrations (\% v/v, $x$-axis), from different wineries (horizontal boxes, A-D) and types of samples taken (vertical boxes). The number of resistant isolates is indicated above the column.

\section{Detection and Distribution of LAB Species}

The multiplex PCR assay was efficient in detecting the principal LAB species in the winery samples (Figure 3 ), however, it was hampered when low LAB populations were present, as in musts and wines at the first stage of MLF. The detection limit reported for this technique is $10^{4} \mathrm{CFU} \cdot \mathrm{ml}^{-1}$ (Petri et al., 2013), and the samples were concentrated 15 times, therefore, populations under $10^{3}$ were not detectable in this study. This detection limit could also explain the lack of recognition of $L$. hilgardii, $L$. plantarum, and L. brevis through this approach in some samples. Another known bias that could explain the lack of detection of certain species is preferential amplification, in which the abundance of certain species, such as $O$. oeni and $P$. parvulus, may have caused reagents to exhaust without amplifying scarce species (Sint et al., 2012).

The species mainly detected in musts (L. plantarum, $P$. parvulus, and L. hilgardii) are widely associated with wine grapes (Renouf et al., 2005; Bae et al., 2006; Barata et al., 2012). The last two are known to produce off-odors (Costello and Henschke, 2002) and biogenic amines in wine (Lonvaud-Funel, 2001), while L. plantarum has been recently regarded as starter culture for MLF (Lerm et al., 2011; Bravo-Ferrada et al., 2013), and has even shown additional advantages due to its capacity of degradation of biogenic amines (Capozzi et al., 2012) as well as better performance in co-inoculation with Saccharomyces cerevisiae (Berbegal et al., 2016). Moreover, the detection of O. oeni in musts is remarkable, given its importance in MLF and since this species is rarely found therein (Bae et al., 2006; Mesas et al., 2011).

In wine, the fact that $O$. oeni and $P$. parvulus were frequently found together suggests some type of association between them, as has been previously posited by Renouf et al. (2007) and Pérez-Martín et al. (2014). Nevertheless, it is important to point out that $P$. parvulus is the species most often involved in ropiness, a major bacterial alteration in wines (Dols-Lafargue et al., 2008). Moreover, the detection of $L$. brevis and L. plantarum only at the beginning of MLF shows a decrease in their populations at advanced stages, 


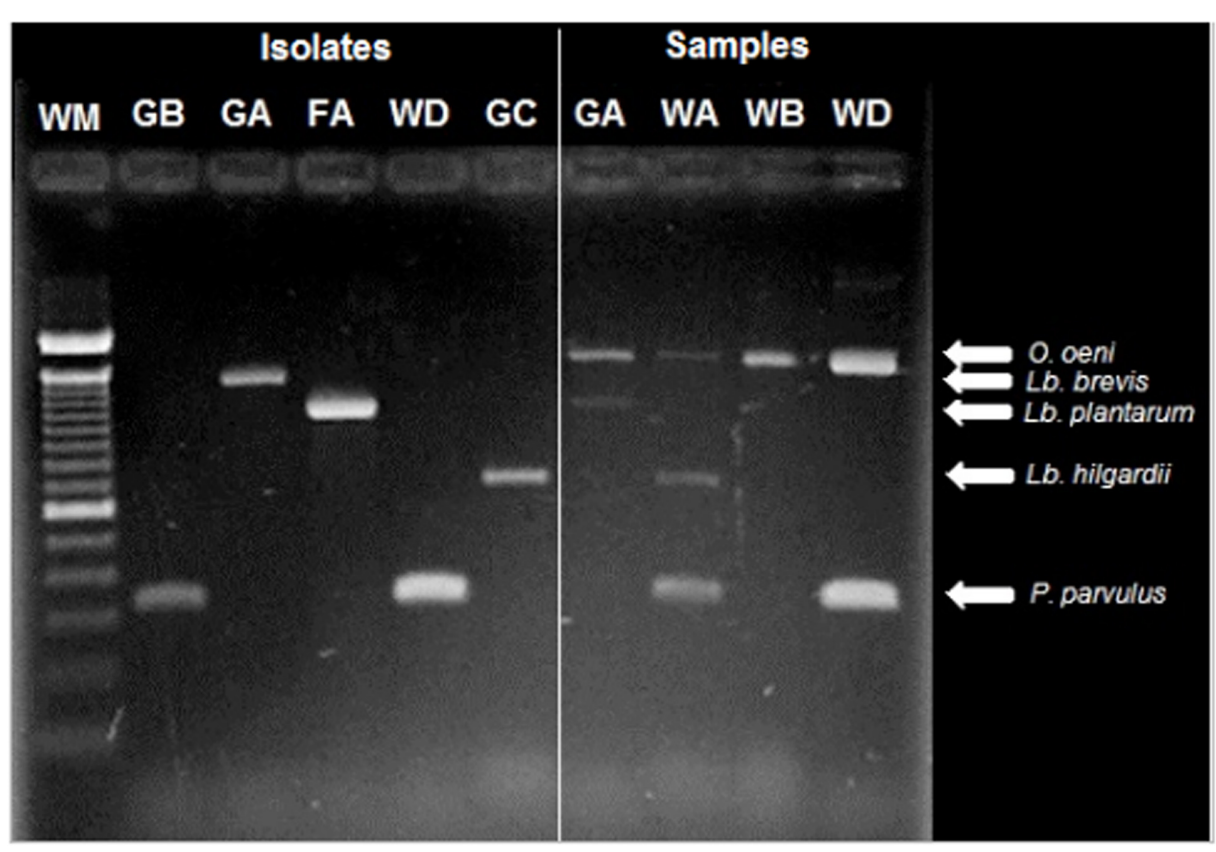

FIGURE 3 | Identification of LAB isolates (lines 2-5) and detection of species present in wine-related (6-9) samples using multiplex PCR. The origin of the sample is indicated above as follows: The first letter corresponds to the type of sample: G, must; F, banel/filter; W, wine. The second letter corresponds to the winery: A, B, C, or D. The first line corresponds to the molecular weight marker Trackit ${ }^{\mathrm{TM}} 100$ bp (Invitrogen). Moreover, the species corresponding to that molecular weight is specified (Petri et al., 2013).

probably due to a low resistance to the modified medium. Finally, the fact that L. hilgardii was only found at the advanced stages of MLF suggests a contamination of the wine, probably through the barrels where this bacterium was also found; this emphasizes the need to implement effective disinfection methods during the winemaking process (González-Arenzana et al., 2013).

Even if the presence of some of these species can lead to wine spoilage, this problem has not been perceived in the local wines; only certain delays or inhibitions of the MLF are apparent. The spoilage features of these bacteria are usually strain-dependent, and for spoilage phenotypes to be produced, not only is the presence of the responsible bacteria required, but also the conducive environmental conditions, for instance, several stress conditions (ethanol, $\mathrm{SO}_{2}$, and low $\mathrm{pH}$ ) promote the production of $\beta$-glucan responsible for ropiness by $P$. parvulus (Dols-Lafargue et al., 2008).

\section{Resistance to Wine-Like Conditions}

In this study, LAB species were challenged with scarce nutrients combined with ethanol, $\mathrm{SO}_{2}$, and low $\mathrm{pH}$, simulating a more realistic representation of what $\mathrm{LAB}$ face during winemaking. One of the principal changes in this process is ethanol concentration, which affects each LAB species differently, and the resistance of each isolate could also vary, depending on its origin (Arroyo-López et al., 2010).

The species showing more tolerant isolates to WLC was O. oeni, which is expected, since this species stands out for its ability to overcome the harsh conditions of wine, enabling it to dominate this media and establish itself in the cellars (LonvaudFunel, 1999). Conversely, higher ethanol levels significantly affected $P$. parvulus, an undesirable, but apparently prevalent species at these wineries. This high susceptibility could be due to the more stressful conditions found in barrels, which could lead to more sensitive strains.

Although L. plantarum has been previously reported with better adaptability to wine than O. oeni (G-Alegría et al., 2004), the isolates evaluated in this study did not show a remarkable performance. Even if Lactobacillus species are considered highly resistant to ethanol (Shane Gold et al., 1992), wines elaborated in Queretaro seldom reach more than $12 \%$ ethanol (De la Cruz-de Aquino et al., 2012), which could explain the lack of adaptation of local strains to $13 \%$ ethanol. Moreover, the fact that a high number of isolates (10 of 19) belonging to Lactobacillus spp. and obtained from winery $\mathrm{C}$ resisted $13 \%$ ethanol was surprising, since they were isolated from must, where they had not been previously exposed to alcohol. Winery $\mathrm{C}$ is the oldest one sampled (about 30 years old), which could have enabled some strains to adapt to both environments, vineyard and cellar. This allowed the identification of resistant strains that could eventually be used as starter cultures, as well as the detection of more hazardous species (and materials) with regard to spoilage.

\section{CONCLUSION}

This is the first report related to the diversity of wine associated LAB in Mexico, and particularly in the wine region of Queretaro. 
Throughout the four wineries studied, five species (O. oeni, $P$. parvulus, L. plantarum, L. hilgardii, and L. brevis) were detected in must, wine, and barrel/filter samples. The species $O$. oeni and L. plantarum were detected at all the wineries and $P$. parvulus was only absent at winery C. L. plantarum and L. brevis were mainly found in musts and at the initial stages of MLF in wines, while L. hilgardii was principally detected at the end of MLF. The highest ethanol concentration tested (13\%) combined with $30 \mathrm{mg} \cdot \mathrm{l}^{-1}$ of $\mathrm{SO}_{2}$ and $\mathrm{pH}$ of 3.5 diminished the number of resistant isolates by around half, regardless of materials origin, with $O$. oeni being the species with a greater proportion of resistant isolates. In contrast, $P$. parvulus and Lactobacillus species obtained from barrel/filters were the most affected by high concentration of ethanol.

\section{AUTHOR CONTRIBUTIONS}

All the authors have revised the present draft, contributed important intellectual content and approved the final version to be published. They have also agreed to be accountable for the content of the work. DM-C: Conception of work, acquisition, analysis and interpretation of data, draft development. RM-P: Conception of work and experimental design, consultation on wine quality aspects. JA-T: Support with data acquisition, molecular techniques, and microbial diversity. MI: Consultation on microbial diversity and microbial kinetic studies. LS-M: Consultation on molecular techniques and data interpretation. JP-A: Consultation on sampling at wineries and microbial metabolism in vineyards. SA-M: Conception and design of work,

\section{REFERENCES}

Arroyo-López, F. N., Salvadó, Z., Tronchoni, J., Guillamón, J. M., Barrio, E., and Querol, A. (2010). Susceptibility and resistance to ethanol in Saccharomyces strains isolated from wild and fermentative environments. Yeast 27, 1005-1015. doi: 10.1002/yea.1809

Asociación de Vitivinicultores de Querétaro [AVQ] (2011). Estudio de impacto productivo de un viñedo. Querétaro: Asociación de Vitivinicultores de Querétaro, 111.

Bae, S., Fleet, G. H., and Heard, G. M. (2006). Lactic acid bacteria associated with wine grapes from several Australian vineyards. J. Appl. Microbiol. 100, 712-727. doi: 10.1111/j.1365-2672.2006.02890.x

Barata, A., Malfeito-Ferreira, M., and Loureiro, V. (2012). The microbial ecology of wine grape berries. In. J. Food Microbiol. 153, 243-259. doi: 10.1016/j.ijfoodmicro.2011.11.025

Bartowsky, E. J. (2009). Bacterial spoilage of wine and approaches to minimize it. Lett. Appl. Microbiol. 48, 149-156. doi: 10.1111/j.1472-765X.2008.02505.x

Berbegal, C., Peña, N., Russo, P., Grieco, F., Pardo, I., Ferrer, S., et al. (2016). Technological properties of Lactobacillus plantarum strains isolated from grape must fermentation. Food Microbiol. 57, 187-194. doi: 10.1016/j.fm.2016.03.002

Bokulich, N. A., Ohta, M., Richardson, P. M., and Mills, D. A. (2013a). Monitoring seasonal changes in winery-resident microbiota. PloS ONE 8:e66437. doi: 10.1371/journal.pone.0066437

Bokulich, N. A., Thomgate, J. H., Richardson, P. M., and Mills, D. A. (2013b). Microbial biogeography of wine grapes is conditioned by cultivar, vintage, and climate. PNAS 111, E139-E148. doi: 10.1073/pnas.1317377110

Bravo-Ferrada, B. M., Hollman, A., Delfederico, L., Valdés La Hens, D., Caballero, A., and Semorile, L. (2013). Patagonian red wines: selection of Lactobacillus plantarum isolates as potential starter cultures for expertise in lactic acid bacteria characterization, data analysis and interpretation, draft development, and financial support management.

\section{FUNDING}

Financial support was provided by Consejo Nacional de Ciencia y Tecnología (CONACYT), México and PRODEP-SEP, México.

\section{ACKNOWLEDGMENT}

The authors thank the Consejo Nacional de Ciencia y Tecnología (CONACYT) of Mexico for the scholarship provided to Dalia Elizabeth Miranda Castilleja during this study, as well as the Asociación de Vitivinicultores de Querétaro (AVQ) and the Escuela de Vino Artesanal (EVA) for facilitating access to the wineries.

\section{SUPPLEMENTARY MATERIAL}

The Supplementary Material for this article can be found online at: http://journal.frontiersin.org/article/10.3389/fmicb. 2016.01769/full\#supplementary-material

FIGURE S1 | Proportion of LAB species recovered in three media from must, wine and barrel/filter rinse: MRS, Man Rogosa Sharpe; MRS-T, MRS added to tomato juice; and MRS-AJ, MRS added to apple juice.

malolactic fermentation. World J. Microbiol. Biotechnol. 29, 1537-1549. doi: 10.1007/s11274-013-1337-x

Capozzi, V., Russo, P., Ladero, V., Fernández, M., Fiocco, D., Alvarez, M. A., et al. (2012). Biogenic amines degradation by Lactobacillus plantarum: toward a potential application in wine. Front. Microbiol. 3:122. doi: $10.3389 /$ fmicb.2012.00122

Carreté, R., Vidal, M. T., Bordons, A., and Constantí, M. (2002). Inhibitory effect of sulfur dioxide and other stress compounds in wine on ATPase activity of Oenococcus oeni. FEMS Microbiol. Lett. 211, 155-159. doi: 10.1111/j.15746968.2002.tb11218.x

Cocolin, L., Alessandria, V., Dolci, P., Gorra, R., and Rantsiou, K. (2013). Culture independent methods to assess the diversity and dynamics of microbiota during food fermentation. Int. J. Food Microbiol. 167, 29-43. doi: 10.1016/j.ijfoodmicro.2013.05.008

Consejo Mexicano Vitivinícola A.C [CMV] (2014). Estadísticas del vino en México. Available at: http://www.uvayvino.org/index.php/noticias/22-economia-y-mer cados/41-estadisticas-del-vino-en-mexico

Costello, P. J., and Henschke, P. A. (2002). Mousy off-flavour of wine: precursors and biosynthesis of the causative N-heterocycles 2-ethyltetrahydropyridine, 2 acetyltetrahydropyridine, and 2-acetyl-1-pyrroline by Lactobacillus hilgardii. J. Agric. Food Chem. 50, 7079-7087. doi: 10.1021/jf020341r

De la Cruz-de Aquino, M. A., Martínez-Peniche, R. A., Becerril-Román, A. E., and Chávaro-Ortíz, M. S. (2012). Physical and chemical characterization of red wines produced in Queretaro. Rev. Fitotec. Mex. 35, 61-67.

Dols-Lafargue, M., Young Lee, H., Le Marrec, C., Heyraud, A., Chambat, G., and Lonvaud-Funel, A. (2008). Characterization of gtf, a glucosiltransferase gene in the genomes of Pediococcus parvulus and Oenococcus oeni, two bacterial species commonly found in wine. Appl. Environ. Microbiol. 74, 4079-4090. doi: 10.1128/AEM.00673-08 
du Toit, M., and Pretorius, I. S. (2000). Microbial spoilage and preservation of wine: using weapons from nature's own arsenal-a review. S. Afr. J. Enol. Vitic. 21, 74-96.

Fleet, G. H. (1993). "The microorganisms of winemaking - isolation, enumeration and identification," in Wine Microbiology and Biotechnology, ed. G. H. Fleet (Chur: Harwood Academic Publisher), 1-26.

G-Alegría, E., López, I., Ruiz, I., Sáenz, J., Férnandez, E., Zaragoza, M., et al. (2004). High tolerance of wild Lactobacillus plantarum and Oenococcus oeni strains to lyophilisation and environmental conditions of acid $\mathrm{pH}$ and ethanol. FEMS Microbiol. Lett. 230, 53-61. doi: 10.1016/S0378-1097(03) 00854-1

Garofalo, C., El Khoury, M., Lucas, P., Bely, M., Russo, P., Spano, G., et al. (2015). Autochthonous starter cultures and indigenous grape variety for regional wine production. J. Appl. Microbiol. 118, 1395-1408. doi: 10.1111/jam.12789

González-Arenzana, L., Pérez-Martín, F., Palop, M. L., Seseña, S., Santamaría, P., López, R., et al. (2015). Genomic diversity of Oenococcus oeni populations from Castilla La Mancha and La Rioja Tempranillo red wines. Food Microbiol. 49, 82-94. doi: 10.1016/j.fm.2015.02.001

González-Arenzana, L., Santamaria, P., López, R., Garijo, P., Gutiérrez, A. R., Garde-Cerdán, T., et al. (2013). Microwave technology as new tool to improve microbiological control of oak barrels: a preliminary study. Food Control 30, 536-539. doi: 10.1016/j.foodcont.2012.08.008

González-Arenzana, L., Santamaria, P., López, R., Tenorio, C., and LópezAlfaro, I. (2012). Ecology of indigenous lactic acid bacteria along with different winemaking processes of Tempranillo red wine from La Rioja (spain). Sci. World J. 2012, 796327. doi: 10.1100/2012/796327

La Hens, D. V., Bravo-Ferrada, B. M., Delfederico, L., Caballero, A. C., and Semorile, L. C. (2015). Prevalence of Lactobacillus plantarum and Oenococcus oeni during spontaneous malolactic fermentation in Patagonian red wines revealed by polymerase chain reaction-denaturing gradient gel electrophoresis with two targeted genes. Aust. J. Grape Wine Res. 21, 49-56. doi: 10.1111/ajgw. 12110

Lerm, E., Engelbrecht, L., and du Toit, M. (2010). Malolactic fermentation: the ABC's of MLF. S. Afr. J. Enol. Vitic. 31, 186-210.

Lerm, E., Engelbrecht, L., and du Toit, M. (2011). Selection and characterization of Oenococcus oeni and Lactobacillus plantarum South African wine isolates for use as malolactic fermentation starter cultures. S. Afr. J. Enol. Vitic. 32, 280-291.

Lonvaud-Funel, A. (1999). Lactic acid bacteria in the quality improvement and depreciation of wine. Antonie Van Leeuwenhoek 76, 317-331. doi: 10.1023/A:1002088931106

Lonvaud-Funel, A. (2001). Biogenic amines in wines: role of lactic acid bacteria. FEMS Microbiol. Lett. 199, 9-13. doi: 10.1111/j.1574-6968.2001.tb10643.x

Mesas, J. M., Rodríguez, M. C., and Alegre, M. T. (2011). Characterization of lactic acid bacteria from musts and wines of three consecutive vintages of Ribera Sacra. Lett. Appl. Microbiol. 52, 258-268. doi: 10.1111/j.1472-765X.2010. 02991.x

Miranda-Castilleja, D. E., Ortíz-Barrera, E., Arvizu-Medrano, S. M., PachecoAguilar, J. R., Aldrete-Tapia, J. A., and Martínez-Peniche, R. A. (2015). Isolation, selection and identification of autochthonous Saccharomyces spp. yeasts from vineyards stablished in Queretaro. Mexico. Agrociencia 49, 759-773.

Pérez-Martín, F., Seseña, S., and Palop, M. L. (2014). Inventory of lactic acid bacteria populations in red wne varieties from Appellation of Origin Méntrida. Eur. Food Res. Technol. 4, 725-733. doi: 10.1007/s00217-014-2377-7

Petri, A., Pfannebecker, J., Fröhlich, J., and König, H. (2013). Fast identification of wine related lactic acid bacteria by multiplex PCR. Food Microbiol. 33, 48-54. doi: 10.1016/j.fm.2012.08.011

Reguant, C., Bordons, A., Arola, L., and Rozés, N. (2000). Influence of phenolic compounds on the physiology of Oenococcus oeni from wine. J. Appl. Microbiol. 88, 1065-1071. doi: 10.1046/j.1365-2672.2000.01075.x
Reguant, C., Carreté, R., Constantí, M., and Bordons, A. (2005). Population dynamics of Oenococcus oeni strains in a new winery and the effect of SO2 and yeast strain. FEMS Microbiol. Lett. 246, 111-117. doi: 10.1016/j.femsle.2005.03.045

Renouf, V., Claisse, O., and Lonvaud-Funel, A. (2005). Understanding the microbial ecosystem on the grape berry surface through numeration and identification of yeast and bacteria. Aust. J. Grape Wine Res. 11, 316-327. doi: 10.1111/j.1755-0238.2005.tb00031.x

Renouf, V., Claisse, O., and Lonvaud-Funel, A. (2007). Inventory and monitoring of wine microbial consortia. Appl. Microb. Cell Physiol. 75, 149-164. doi: 10.1007/s00253-006-0798-3

Renouf, V., Delaherche, A., Claisse, O., and Lonvaud-Funel, A. (2008). Correlation between indigenous Oenococcus oeni strain resistance and the presence of genetic markers. J. Ind. Microbiol. Biotechnol. 35, 27-33. doi: 10.1007/s10295007-0262-0

Rodas, A. M., Ferrer, S., and Pardo, I. (2003). 16S-ARDRA, a tool for identification of lactic acid bacteria isolated from grape must and wine. Syst. Appl. Microbiol. 26, 412-422. doi: 10.1078/072320203322497446

Ruiz, P., Izquierdo, P. M., Seseña, S., and Palop, M. L. (2008). Intraespecific genetic diversity of lactic acid bacteria from malolactic fermentation of Cencibel wines as derived from combined analysis of RAPD-PCR and PFGE patterns. Food Microbiol. 25, 942-948. doi: 10.1016/j.fm.2008.06.007

Saguir, F. M., Loto, C. I. L., Maturano, C., and de Nadra, M. C. (2009). Identification of dominant lactic acid bacteria isolated from grape juices. Assessment of its biochemical activities relevant to flavor development in wine. Int. J. Wine Res. 1, 175-185. doi: 10.2147/IJWR.S4567

Schillinger, U., and Holzapfel, W. H. (2012). "Culture media for lactic acid bacteria," in Handbook Culture Media for Food and Water Microbiology, 3rd Edn, eds J. Corry, G. Curtis, and R. Baird (Cambridge: Royal Society of Chemistry), 181.

Shane Gold, R., Meagher, M. M., Hutkins, R., and Conway, T. (1992). Ethanol tolerance and carbohydrate metabolism in lactobacilli. J. Ind. Microbiol. 10, 45-54. doi: 10.1007/BF01583633

Sint, D., Raso, L., and Traugott, M. (2012). Advances in multriplex PCR; balancing primer efficiencies and improving detection success. Methods Ecol. Evol. 3, 898-905. doi: 10.1111/j.2041-210X.2012.00215.x

Solieri, L., Genova, F., De Paola, M., and Giudici, P. (2010). Characterization and technological properties of Oenococcus oeni strain from wine spontaneous malolactic fermentations: a framework for selection of the new starter cultures. J. Appl. Microbiol. 108, 285-298. doi: 10.1111/j.1365-2672.2009.04428.x

Soto-Muñoz, L., Teixidó, N., Usall, J., Viñas, I., and Torres, R. (2014). Detection and quantification by PCR assay of the biocontrol agent Pantoea agglomerans CPA-2 on apples. Int. J. Food Microbiol. 175, 45-52. doi: 10.1016/j.ijfoodmicro.2014.01.014

Spano, G., and Massa, S. (2006). Environmental stress response in wine lactic acid bacteria: beyond Bacillus subtillis. Crit. Rev. Microbiol. 32, 77-86. doi: 10.1080/10408410600709800

Conflict of Interest Statement: The authors declare that the research was conducted in the absence of any commercial or financial relationships that could be construed as a potential conflict of interest.

Copyright (C) 2016 Miranda-Castilleja, Martínez-Peniche, Aldrete-Tapia, SotoMuñoz, Iturriaga, Pacheco-Aguilar and Arvizu-Medrano. This is an open-access article distributed under the terms of the Creative Commons Attribution License (CC BY). The use, distribution or reproduction in other forums is permitted, provided the original author(s) or licensor are credited and that the original publication in this journal is cited, in accordance with accepted academic practice. No use, distribution or reproduction is permitted which does not comply with these terms. 